\title{
Angiotensin Receptors Blockers and Cognition in Elderly Home Residents
}

\section{Hamza SA, Adly NN, Ekramy E. Abdelrahman EE, Fouad IM}

Geriatric Medicine \& Gerontology department, Faculty of Medicine, Ain Shams University, Cairo, Egypt.

\section{Abstract}

Background: Cognitive impairment and hypertension are prevalent in elderly. There is controversial data regarding the impact of angiotensin receptor blockers (ARBs) on cognition.

Aim: To study studied the relation between angiotensin receptor blockers (ARBs) and cognition.

Methods: A case control study was conducted among Cairo's elderly home residents, aged $\geq 60$ years old, between users $(n=10)$ and non-users $(n=67)$ of ARBs among hypertensive elderly in long term care centers.

Results: There was no significant difference between users and non-users of ARBs in MMSE, age, systolic blood pressure (SBP), diastolic blood pressure (DBP) $(P=0.76,0.54,0.66$ and 0.37 consecutively).

Conclusions: No sufficient evidence supports the relation between ARBs and cognition in a sample of hypertensive elderly.

Keywords: Hypertensive, Cognition,ARBs

\section{Background:}

Cognitive impairment is estimated to be $17 \%-36 \%$ of adults aged $\geq 65$ years old in the United States ${ }^{1}$ and in many cases evolves to dementia. ${ }^{2}$

When elders suffer from cognitive impairment, they are at increased risk of nursing home placement. ${ }^{3}$

Several epidemiological surveys conducted in the USA and Europe conclude that hypertension prevalence in the elderly ranges between $53 \%$ and $72 \%{ }^{4}$

Cardio-selective medications such as angiotensin enzyme inhibitors (ACEIs), angiotensin receptor blockers (ARBs) and beta blockers are considered lifesustaining drugs because they reduce mortality and morbidity. ${ }^{5-7}$

The effects of ARBs on cognition are controversial. ${ }^{8,9}$

However, most of the studies were conducted upon patients with heart failure. ${ }^{10}$

Aim of the current study was to assess cognitive functions between users and non-users of ARBs among hypertensive elderly in long term care centers.

\section{Methods}

A case control study was conducted among Cairo's elderly home residents, aged $\geq 60$ years old, between users $(n=10)$ and non-users $(n=67)$ of ARBs among hypertensive elderly in long term care centers.

A Comprehensive Geriatric Assessment was carried out for each participant including full medical history, Clinical examination and assessment of the cognitive status by using the Arabic version7 of the Mini Mental state examination (MMSE). Which is one of the most commonly used global cognitive screening measures because it is quick and easy to administer. The test score is based on 30 total points. ${ }^{11,12}$

Inclusion criteria:

Hypertensive elderly aged $\geq 60$ years old. 
Exclusion criteria: Patients using ACEIs.

\section{Statistical Analysis}

The data were analyzed using Statistical Package for the Social Sciences (SPSS) version 16 (SPSS Inc., Chicago, IL, USA).

Qualitative data were presented in the form of frequency tables. Quantitative data were presented in the form of means and SD or median (interquartile) values. Differences between two groups were assessed using the Student's t-test. For qualitative data, the Chisquare test was used to compare between the two groups.

\section{Results}

Seventy seven patients were included. The mean age of the study group was $69.1 \pm 6.2$, among participants 13 $\%$ were on ARBs (Table 1). There was no significant difference between users and non-users of ARBs in MMSE, age, systolic blood pressure (SBP), diastolic blood pressure (DBP) $(\mathrm{P}=0.76,0.54,0.66$ and 0.37 consecutively)(Table 2).

In addition, there was no difference between users and non-users of ARBs in gender distribution, current smoking status, diabetes mellitus and stroke $(\mathrm{P}=0.4$, $0.68,0.3$ and 0.35 consecutively)(Table 2 ).

Table 1: Demography of the study population

\begin{tabular}{|l|l|}
\hline Variable & Distribution \\
\hline Age & $69.1 \pm 6.2$ \\
\hline Male gender & $46(59.7 \%)$ \\
\hline Diabetes mellitus & $25(32.5 \%)$ \\
\hline Smoker & $46(59.7 \%)$ \\
\hline stroke & $14(18.2 \%)$ \\
\hline Heart failure & $8(10.4 \%)$ \\
\hline MMSE & $26.9 \pm 1.9$ \\
\hline Systolic blood pressure & $128.8 \pm 11.5$ \\
\hline Diastolic blood pressure & $81 \pm 7.9$ \\
\hline
\end{tabular}

Table 2: Comparing between users and non-users of ARBs

\begin{tabular}{|l|l|l|l|}
\hline Variable & Users & $\begin{array}{l}\text { Non- } \\
\text { users }\end{array}$ & $\begin{array}{l}\text { P } \\
\text { value }\end{array}$ \\
\hline Age & $68.3 \pm 4$ & $69.2 \pm 6.5$ & 0.54 \\
\hline Male gender & $5(50 \%$ & $\begin{array}{l}22 \\
(64.7 \%)\end{array}$ & 0.4 \\
\hline Current smoking & $3(30 \%)$ & $\begin{array}{l}8 \\
(23.5 \%)\end{array}$ & 0.68 \\
\hline Diabetes mellitus & $4(40 \%)$ & $\begin{array}{l}8 \\
(23.5 \%)\end{array}$ & 0.3 \\
\hline Stroke & $1(8 \%)$ & $\begin{array}{l}8 \\
(23.5 \%)\end{array}$ & 0.35 \\
\hline MMSE & $26.8 \pm$ & $26.9 \pm 1.9$ & 0.76 \\
\hline Systolic blood pressure & $\begin{array}{l}1.7 \\
14.2\end{array}$ & $\begin{array}{l}129 \pm \\
10.9\end{array}$ & 0.66 \\
\hline Diastolic blood pressure & $79 \pm 7.4$ & $81 \pm 7.9$ & 0.37 \\
\hline
\end{tabular}

Using generalized linear method for regression, ARBs were not significant predictor for MMSE, even after adjustment to history of diabetes mellitus, stroke and smoking, , gender, SBP, DBP and age $(\mathrm{P}=0.76)$.

\section{Discussion:}

The relation between antihypertensive medications and cognition is still in need for further work as declared by Yasar et al. in a recent review of human studies. ${ }^{13}$

Current data revealed no significant difference between users and non-users of ARBs among hypertensive elderly.

These results are in agreement with Athilingam et al who studied ARBs in patients with heart failure and found that The Montreal Cognitive Assessment total score was not associated with ARBs. ${ }^{10}$

This was not the case $\mathrm{Li}$ et al who declared that Angiotensin receptor blockers were associated with a significant reduction in the incidence and progression of Alzheimer's disease and dementia in a predominantly male population. ${ }^{14}$

This discrepancy with the current results may be attributed to the difference in the study population as $\mathrm{Li}$ et al studied participants with existing dementia, following their progression and admission to nursing homes.

However, Goh et al in a cohort study found a small reduction in dementia risk with ARBs in comparison to ACEIs. However, the strongest association was seen in early follow-up, suggesting that the inverse association is unlikely to be causal, but instead reflects other important but unmeasured differences between ARBs and ACEIs users. ${ }^{15}$

Similarly, absence of relationship between ARBs use and mitigation of cognitive decline was declared by other authors. ${ }^{16-18}$

ARBs block the actions of Angiotensin II via the AT1 receptor regardless of the biochemical pathway leading to Angiotensin II formation. ${ }^{19}$

This controversy might be explained by the rat model, in which $\mathrm{AT}_{1}$ receptor blockade increases vascular $\mathrm{AT}_{2}$ receptor expression and interrupts Angiotensin II negative feedback on renin secretion stimulating the production of Angiotensin II, which is available to act at unblocked AT2 receptors. ${ }^{20}$ However, this needs to be further elucidated in human.

\section{Conclusion:}

No sufficient evidence supports the relation between ARBs and cognition in a sample of hypertensive elderly.

\section{References:}

1. Koenig HG, Blazer DG. Epidemiology of geriatric affective disorders. Clin Geriatr Med. 1992;8:235-251.

2. Hanninen T, Hallikainen M, Koivisto K, et al. A follow-up study of ageassociated memory impairment: neuropsychological predictors of dementia. J 
Am Geriatr Soc. 1995;43:1007-1015

3. Fisher K \& Shumaker L. Assessment of Depression and Cognitive impairment among Elders in Rural Housing Facilities. J Am Psychiatr Nurses Assoc 2004;10(2):67-72.

4. Sundquist J, Winkleby MA, Pudaric S. Cardiovascular disease risk factors among older black, Mexican-American and white women and men: an analysis of NHANES III, 1988-1994. Third National Health and Nutrition Examination Survey. J Am Geriatr Soc 2001; 49(2):109-116.

5. Ong HT. Are angiotensin-converting enzyme inhibitors and angiotensin receptor blockers especially useful for cardiovascular protection? J Am Board Fam Med. 2009; 22(6):686-97.

6. Gard PR. Review. Cognitive-enhancing effects of angiotensin IV. BMC Neuroscience. 2008, 9(Suppl 2):S15doi:10.1186/1 471-2202-9-S2-S15

7. McKelvie R (2010). Heart failure. Online version of BMJ Clinical Evidence. Retrieved on May 2011 from http://www.clinicalevidence.com.

8. Ferrrington L, Minerrs JS, Palmer LE, et al. Angiotensin II-inhibiting drugs have no effect on intraneuronal $A \beta$ or oligomeric $A \beta$ levels in a triple transgenic mouse model of Alzheimer's disease. Am J Transl Res. 2011;3(2):197-03.

9. Tarawneh R, Galvin JE. Potential Future Neuroprotective Therapies for Neurodegenerative Disorders and Stroke. Clin Geriatr Med. 2010; 26 (1): 125. 47

10. Athilingam P, Munro C, D'aoust R, Karch A, Chen L. Cognitive protection by angiotensin converting enzyme inhibitors in heart failure. International Journal of Nursing Science. 2012;2(3):14-22

11. Folstein MF, Folstein SE, McHugh PR. "MiniMental State": a practical method for grading the cognitive state of patients for the clinician. J Psychiatr Res 1975:12:189-98.

12. El Okl, M.A., et al. (2002) Prevalence of Alzheimer Dementia and Other Causes of Dementia in Egyptian Elderly. MD Thesis, Faculty of Medicine, Ain Shams University, Cairo

13. Yasar S, Schuchman M, Peters J, Anstey KJ, Carlson MC, Peters R. Relationship Between Antihypertensive Medications and Cognitive Impairment: Part I. Review of Human Studies and Clinical Trials. Curr Hypertens Rep. 2016 Aug;18(8):67

14. Li NC, Lee A, Whitmer RA, et al. Use of angiotensin receptor blockers and risk of dementia in a predominantly male population: prospective cohort analysis. BMJ. 2010: 340, 1-10.

15. Goh KL, Bhaskaran K, Minassian C, Evans SJ, Smeeth L, Douglas IJ. Angiotensin receptor blockers and risk of dementia: cohort study in UK Clinical Practice Research Datalink.Br J Clin Pharmacol. 2014.

16. Anderson C, Teo K, Gao P, Arima H, Dans A, Unger T, et al. ONTARGET and TRANSCEND Investigators. Renin-angiotensin system blockade and cognitive function in patients at high risk of cardiovascular disease: analysis of data from the ONTARGET and TRANSCEND studies. Lancet Neurol. 2011:10(1):43-53.

17. Hsu CY, Huang CC, Chan WL, Huang PH, Chiang CH, Chen TJ, et al. Angiotensin-receptor blockers and risk of Alzheimer's disease in hypertension population-a nationwide cohort study. Circ J Circulation Society. 2013;77:40510.

18. Wagner G, Icks A, Abholz HH, Schroder-Bernhardi D, Rathman W, Kostev $\mathrm{K}$. Antihypertensive treatment and risk of dementia: a retrospective database study. Int J ClinPharmacolTher. 2012;50:195-201

19. Al Sabbah Z, Mansoor A, Kaul U. Angiotensin Receptor Blockers. Advantages of the New Sartans. JAPI 2013: 61

20. Carey RM. Angiotensin Receptors and Aging. Hypertension. 2007;50:1-2. 